\title{
Comparison of Skin Scraping and Standard Superficial Skin Biopsy in the Laboratory Diagnosis of Scabies
}

\author{
Uyuzun Laboratuvar Tanısinda Deri Kazıntısı ve Standart Yüzeysel Deri \\ Biyopsi Yöntemlerinin Karşılaştırılması
}

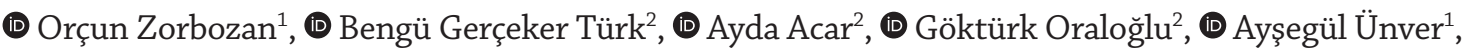 (1) Seray Töz ${ }^{1}$, (1) İdil Ünal ${ }^{2}$, (1) Nevin Turgay ${ }^{1}$

${ }^{1}$ Ege University Faculty of Medicine, Department of Parasitology, İzmir, Turkey

${ }^{2}$ Ege University Faculty of Medicine, Department of Dermatology, İzmir, Turkey

Cite this article as: Zorbozan O, Gerçeker Türk B, Acar A, Oraloğlu G, Ünver A, Töz S, Ünal İ, Turgay N. Comparison of Skin

Scraping and Standard Superficial Skin Biopsy in the Laboratory Diagnosis of Scabies. Turkiye Parazitol Derg 2020;44(3):164-7.

\begin{abstract}
Objective: Scabies is diagnosed based on the presence of burrows on the skin, Sarcoptes scabiei adult, egg, or scybala in skin scrapings. The laboratory diagnosis of scabies poses various challenges. We aimed to compare the analytical performance of skin scraping and standard superficial skin biopsy (SSSB) and to investigate the correlation with false negative results in the laboratory diagnosis of scabies.

Methods: Skin scraping and SSSB were applied from July 1 to December 31, 2018 on 42 patients whose burrows were marked using dermatoscopy, as obtained from the laboratory information system.

Results: The number of patients who tested positive for scabies with skin scraping was 18 (42.9\%) and 24 (57.1\%) with SSSB, and the difference was significant $(\mathrm{p}=0.003$ ). Sensitivity was $42.9 \%$ for skin scraping and $57.1 \%$ for SSSB. The number of positive cases with both techniques was 15 (35.7\%). The number of patients positive with only skin scraping was $3(7.1 \%)$ and only SSSB was 9 (21.4\%).

Conclusion: To date, it has seemed impossible to diagnose scabies using a single clinical or laboratory test. According to our results, SSSB is an inexpensive and easy-to-apply method with high sensitivity for obtaining skin samples for scabies laboratory diagnosis.
\end{abstract}

Keywords: Scabies, standard superficial skin biopsy, skin scraping, analytical performance

öz

Amaç: Uyuz tanısı karakteristik klinik belirtilerin varlığı, deride silyonların ve/veya Sarcoptes scabiei erişkin, yumurtaları veya dışkılarının gösterilmesiyle konulmaktadır. Uyuzun laboratuvar tanısında çeşitli sorunlar yaşanmaktadır. Bu çalışmada geriye dönük olarak uyuzun laboratuvar tanısında deri kazıntısı ve standart yüzeysel deri biyopsisi (SYDB) ile yapılan mikroskopik incelemenin analitik performansını karşılaştırmayı ve yalancı negatiflik sorunu ile korelasyonunu araştırmayı amaçladık.

Yöntemler: Çalışmada 1 Temmuz - 31 Aralık 2018 tarihleri arasında silyonları dermatoskopi ile işaretlenen ve işaretli alandan deri kazıntısı ve sonrasında SYDB yapılan 42 hastanın verileri geriye dönük olarak laboratuvar bilgi sisteminden elde edilmek suretiyle incelenmiştir.

Bulgular: Deri kazıntısı ile yapılan incelemede pozitif sonuç alınan hasta sayısı $18(\% 42,9)$ iken aynı hastaların SYDB ile yapılan incelemelerinde $24(\% 57,1)$ hastada pozitif olarak sonuçlandı ve aradaki fark istatistiksel olarak anlamlıdı $(\mathrm{p}=0,003)$. Deri kazıntısının duyarlılığı \%42,9, SYDB'nin duyarlılığı \%57,1 olarak hesaplandı. Her iki yöntemle de pozitif sonuçlanan hasta sayısı $15(\% 35,7)$ iken sadece deri kazıntısı ile pozitif olan hasta sayıs $3(\% 7,1)$, sadece SYDB ile pozitif olan hasta say1s1 $9(\% 21,4)$ olarak tespit edildi.

Sonuç: Mevcut durumda tek başına klinik veya laboratuvar testleri ile tanı konmak mümkün görünmemektedir. Uyuzun laboratuvar tanısında SYDB; ucuz, uygulaması kolay ve elde ettiğimiz bulgulara göre deri kazıntısına göre daha duyarlı bir yöntemdir.

Anahtar Kelimeler: Uyuz, standart yüzeysel deri biyopsisi, deri kazıntısı, analitik performans 


\section{INTRODUCTION}

Scabies is a skin infestation of the mite called Sarcoptes scabiei var. hominis (S. scabiei) which is characterized by erythematous papule and excoriations with severe pruritus (1). The mites live within burrows that they formed in the skin of the host. The signs and symptoms of the disease occur as a result of the allergic reaction to the both mite itself and to the eggs and extracts of the mites. Diagnosis of the disease is based on the presence of characteristic clinical symptoms, presence of burrows in the skin and/or $S$. scabiei adult, egg or scybala (feces) in the skin scraping specimens (2).

Dermatoscopy is a non-invasive diagnostic technique used in the daily practice of dermatology, which allows the examination of skin lesions with various magnifications. For the dermatoscopic diagnosis of scabies, a small black triangular structure and a linear trace of white air bubbles following this structure should be seen. This image is called "jet with contrail" (3). Although bypassing of laboratory may not cause a problem for immunocompetent patients in tertiary healthcare settings which has an opportunity of dermatoscopy, but it may be problematic for immunosuppressed cases or patients with co-morbidity in primary healthcare setting with limited opportunities.

Laboratory diagnosis of scabies is via microscopic examination of skin scrapings from the body parts where burrows are seen. Mites usually prefer thin and wet skin regions to live in, thus it is not always possible to yield a sufficient skin scraping material. While the presence of S. scabiei adult, egg or scybala in the skin scraping specimens is a definitive diagnosis, negative results cannot rule out scabies. The diagnostic sensitivity of microscopic examination with skin scraping materials were reported approximately $46 \%$ in various researches $(2,4)$. Above mentioned problems about the laboratory diagnosis of scabies distract the clinicians from laboratory consultation.

In this study, it was aimed to compare the analytical performance of two distinct sampling methods retrospectively in which cases burrows were shown via dermatoscopy and to investigate the correlation with false negativity problem in the laboratory diagnosis of scabies.

\section{METHODS}

Standard superficial skin biopsy (SSSB), a method which is used in the laboratory diagnosis of Demodex mite infestations, is routinely applied for the laboratory diagnosis of scabies in our laboratory, in addition to skin scraping method to increase the diagnostic sensitivity. Dermatoscopic examination is made by using a polarized handheld dermatoscope with $x 10$ magnification (Derm Lite DL4; 3Gen Inc.; San Juan Capistrano, CA). Dermatoscopic photographing is performed with using a polarized light immersion dermatoscopic camera (DermLite Foto System, 3Gen, San Juan Capistrano, CA, USA) and burrows are marked in dermatology clinic. At first, skin scraping is applied to burrows (Figure 1A) that are marked via dermatoscopy as described; skin scrapings are obtained by using the edge of a sterile scalpel, the scraped material is transferred to a slide and covered with a coverslip (4). And then SSSB is applied to the same area with a drop of cyanoacrylate on a slide. Resulting materials are investigated under light microscope with x100 magnification. Presence of adult mite, egg or scybala is reported as positive for $S$. scabiei (Figure 1B). The microscope image of the samples obtained from the same case by two different methods is shown in figure $2 \mathrm{~A}$ and figure $2 \mathrm{~B}$.

The data of the skin scraping and SSSB results of the patients, which had burrows marked via dermatoscopy from July 1 to December 31, 2018, obtained from the laboratory information system. The detection of one or more burrows in dermatoscopy was accepted as the gold standard scabies diagnosis. The analytical performance of two distinct sampling methods were compared based on gold standard method.

\section{Statistical Analysis}

Statistical analysis was performed via the software SPSS v.20 (IBM, USA). Chi-square analysis was performed for categorical data. While all the expected values were above 5 on chi-square table, Pearson chi-square was used. Statistical significance limit for Pearson chi-square test was $\mathrm{p}<0.05$.

\section{RESULTS}

The number of patients who had burrows showed in dermatoscopy was 42 (19 females, 23 males). The mean age of patients was 39 years (range; 3-72 years). The number of patients positive for scabies with skin scraping method was 18 (42.9\%), while 24 (57.1\%) with SSSB method (Table 1) and the difference was statistically significant $(\mathrm{p}=0.003)$. The number of patients positive for scabies with both methods was 15 (35.7\%). The number of patients positive for scabies with only one method was 3 (7.1\%) for skin scraping and 9 (21.4\%) for SSSB (Table 2).

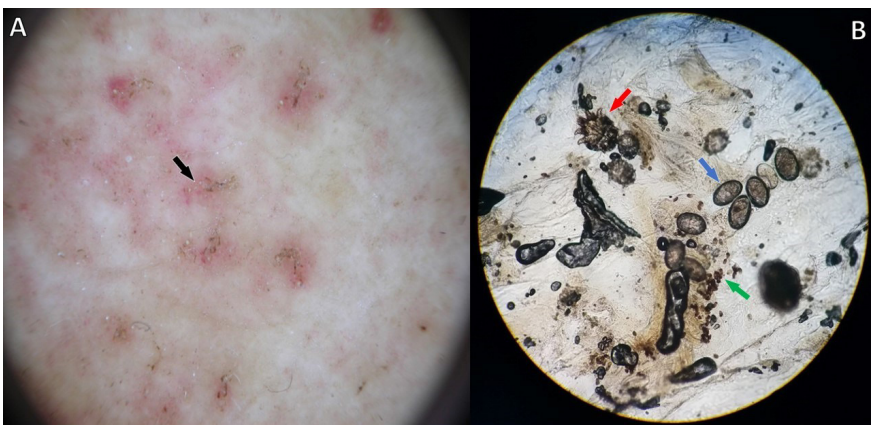

Figure 1. A) "Jet with contrail" (black arrow) via dermatoscopy (x10 magnification), B) Adult (red arrow), egg (blue arrow) and scybala (green arrow) of Sarcoptes scabiei var. hominis under light microscope (x100 magnification)

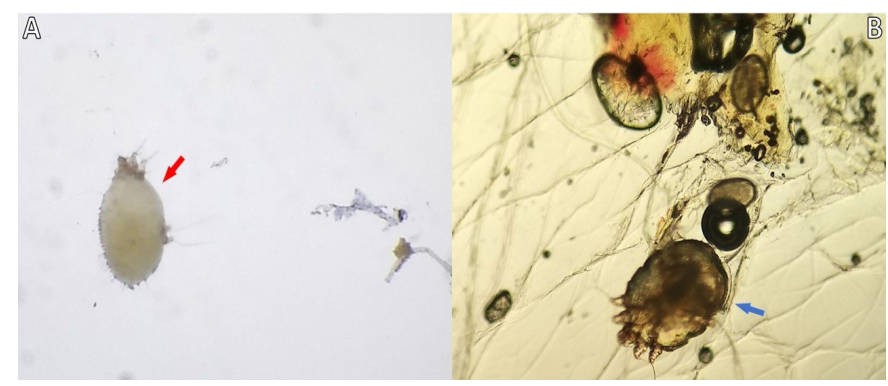

Figure 2. Adult of Sarcoptes scabiei var. hominis under light microscope A) in skin scraping sample (red arrow) and B) SSSB sample (blue arrow) (x100 magnification)

SSSB: Standard superficial skin biopsy 
Table 1. Laboratory results of the patients with two sampling methods whose burrows marked via video dermatoscopy

\begin{tabular}{|l|l|l|l|}
\hline & $\begin{array}{l}\text { S.scabiei } \\
\text { detected }\end{array}$ & $\begin{array}{l}\text { S.scabiei not } \\
\text { detected }\end{array}$ & Sensitivity* \\
\hline $\begin{array}{l}\text { Skin scraping } \\
\text { method }\end{array}$ & 18 & 24 & $42.9 \%$ \\
\hline $\begin{array}{l}\text { Standard } \\
\text { superficial skin } \\
\text { biopsy method }\end{array}$ & 24 & 18 & $57.1 \%$ \\
\hline${ }^{*}: \mathrm{p}=0.003$ & \multicolumn{3}{|l}{} \\
\hline
\end{tabular}

Table 2. Comparison of the laboratory results with skin scraping and standard superficial skin biopsy methods

\begin{tabular}{|l|l|l|l|}
\hline & $\begin{array}{l}\text { SSSB } \\
\text { positive }\end{array}$ & $\begin{array}{l}\text { SSSB } \\
\text { negative }\end{array}$ & Total \\
\hline Skin scraping positive & 15 & 3 & 18 \\
\hline $\begin{array}{l}\text { Skin scraping } \\
\text { negative }\end{array}$ & 9 & 15 & 24 \\
\hline Total & 24 & 18 & 42 \\
\hline SSSB: Standard superficial skin biopsy & & \\
\hline
\end{tabular}

\section{DISCUSSION}

Scabies is a neglected public health problem both in developed and resource-poor countries (5). The effect of poor hygiene in the prevalence of scabies is incidental and overcrowding is reported as main predisposing factor in the literature (5). Outbreaks in residential and long-term care facilities are usually caused by delayed diagnosis and are difficult to control (6). Therefore, early diagnosis is crucial.

In the year 2018, a significant increase in the number of scabies cases was observed in our hospital. Annual number of "Skin Scraping test" requests was 46 for the year 2017 and 4 cases were positive for S. scabiei in microscopic examination (8.7\%), while this number was 248 for the year 2018 and and 86 cases were positive for S. scabiei in microscopic examination (34.7\%). However, the number of laboratory consultations is not at a desired level, as a result of both usage of video dermatoscopy and presence of problems in the laboratory diagnosis.

In ideal conditions, the diagnosis of scabies is made by the evaluation of both the clinical features such as the patient's history of contact, rashes observed in the skin due to pruritus, increased itching at night and the data obtained by dermatoscopy and laboratory diagnostic methods $(7,8)$. The mite is seen as a dark triangular shape (jet with contrail) at the end of the burrow on dermatoscopy. Laboratory diagnosis can be done by showing S. scabiei adult, egg or scybala in the skin scraping specimens (9). However, in practice, there are various problems in the diagnosis of scabies in both clinical and laboratory stages. In the clinical stage, it is difficult to diagnose because the symptoms of the disease can mimic many other skin diseases and the clinical findings can often be masked by secondary infections $(2,9,10)$. The mean number of mites present in the body at the initial stage of scabies was reported to be 11.2 (11). Both the low number of mites and distortion of burrows due to secondary infections and scratching reduce the sensitivity of dermatoscopy and laboratory diagnostic methods. Diagnosing via treatment is also misleading for scabies (7). The response to treatment cannot exclude the possibility that the symptom of skin disease other than scabies has disappeared spontaneously. Considering the increased drug resistance in recent years, the lack of response to treatment cannot exclude scabies also.

The treatment for scabies and the other skin diseases in the differential diagnosis of scabies are quite different from each other (12). Iatrogenic immunosuppression with corticosteroid treatment due to a false negative result in scabies diagnosis can lead to the conversion of the ordinary scabies to even more severe and fatal crusted scabies $(13,14)$.

Because of the above-mentioned issues about the diagnosis, a negative result obtained by any diagnostic method cannot exclude scabies, even for an experienced specialist. Therefore, it is very important to minimize the false-negativity and to increase the sensitivity of diagnostic methods as much as possible, for reducing the prevalence of this contagious disease. In this context, SSSB, a less invasive method which is used in the laboratory diagnosis of Demodex mite infestations (15), is routinely applied for the laboratory diagnosis of scabies in our laboratory in addition to skin scraping method.

The sensitivity value calculated for the microscopic examination of the samples taken by the skin scraping method for laboratory diagnosis of scabies in the presented study is similar to the sensitivity values reported in the literature $(2,4)$. In our study, SSSB method has been shown to have significantly higher sensitivity than skin scraping method for laboratory diagnosis of scabies. In the literature, the studies using the SSSB method for scabies diagnosis are limited (16). Katsumata and Katsumata (17) has described the use of Adhesive Tape test which has a similar mechanism with SSSB in the laboratory diagnosis of scabies, but its sensitivity has been reported to be low compared to skin scraping. Walter et al. (4) reported a sensitivity of $68 \%$ in the study they applied the adhesive tape method and this value is higher than the $57.1 \%$ sensitivity we calculated for SSSB in our study. In Walter et al. (4) study, taking three separate adhesive tape samples from each patient is thought to be the reason for this difference. It is considered that the sensitivity of the SSSB method can be increased by multiple sampling. In another study in which adhesive tape method was used, sensitivity was reported as $16 \%$ and lack of dermatoscopy was considered as the reason for low sensitivity (18).

There are various advantages and disadvantages of SSSB compared to skin scraping. The area of the material obtained with SSSB is larger and all layers of epidermis can be seen homogeneously. Thus, the probability to show the mite is increased. SSSB does not cause bleeding, therefore it is more comfortable for patient and has low risk for secondary infections. Because there is no need for using surgical blade in SSSB, the laboratory cost is low. However, the material obtained with SSSB is not suitable for Molecular tests due to the dried cyanoacrylate residues.

\section{CONCLUSION}

It is not seemed as possible to diagnose scabies with a single clinical or laboratory test to date. The SSSB is a cheap, easy to apply and more sensitive method for obtaining skin samples for scabies laboratory diagnosis. The establishment of clinical and laboratory cooperation and usage of all diagnostic methods in coordination thought to increase the chance of correct diagnosis and appropriate treatment. 


\section{* Ethics}

Ethics Committee Approval: Since this is a retrospective study, ethics committee approval was not obtained.

Informed Consent: Since this is a retrospective study, informed consent was not obtained.

Peer-review: Internally peer-reviewed.

\section{* Authorship Contributions}

Surgical and Medical Practices: O.Z., A.A., G.O., Concept: O.Z., B.G.T., A.A., G.O., A.Ü., S.T., İ.Ü., N.T., Design: O.Z., B.G.T., A.A., G.O., A.Ü., S.T., İÜ., N.T., Data Collection or Processing: O.Z., A.A., G.O., Analysis or Interpretation: O.Z., B.G.T., A.A., G.O., A.Ü., S.T., İ.Ü., N.T., Literature Search: O.Z., B.G.T., A.A., Writing: O.Z.

Conflict of Interest: No conflict of interest was declared by the authors.

Financial Disclosure: The authors declared that this study received no financial support.

\section{REFERENCES}

1. Khalil S, Abbas O, Kibbi AG, Kurban M. Scabies in the age of increasing drug resistance. PLoS Negl Trop Dis 2017; 11: e0005920.

2. Walton SF, Currie BJ. Problems in diagnosing scabies, a global disease in human and animal populations. Clin Microbiol Rev 2007; 20: 268-79.

3. Argenziano G, Fabbrocini G, Delfino M. Epiluminescence microscopy. A new approach to in vivo detection of Sarcoptes scabiei. Arch Dermatol 1997; 133: 751-3.

4. Walter B, Heukelbach J, Fengler G, Worth C, Hengge U, Feldmeier H. Comparison of dermoscopy, skin scraping, and the adhesive tape test for the diagnosis of scabies in a resource-poor setting. Arch Dermatol 2011; 147: 468-73.

5. Ong CY, Vasanwala FF. Infected with scabies again? Focus in management in long-term care facilities. Diseases 2018; 7: 3.

6. Cassell JA, Middleton J, Nalabanda A, Lanza S, Head MG, Bostock J, et al. Scabies outbreaks in ten care homes for elderly people: A prospective study of clinical features, epidemiology, and treatment outcomes. Lancet Infect Dis 2018; 18: 894-902.

7. Thomas J, Peterson GM, Walton SF, Carson CF, Naunton M, Baby KE. Scabies: an ancient global disease with a need for new therapies. BMC Inf Dis 2015; 15: 250.

8. Engelman D, Steer AC. Control strategies for scabies. Trop Med Infect Dis 2018; 3: 98 .

9. Chosidow O. Clinical practices. Scabies. New Eng J Med 2006; 354: 171827.

10. Johnston G, Sladden M. Scabies: diagnosis and treatment. BMJ 2005; 331: 619-22.

11. Arlian LG, Morgan MS. A review of Sarcoptes scabiei: past, present and future. Parasites Vectors 2017; 10: 297.

12. Jacks SK, Lewis EA, Witman PM. The Curette Prep: A modification of the traditional scabies preparation. Pediatr Dermatol 2012; 29: 544-5.

13. Yélamos O, Mir-Bonafé JF, López-Ferrer A, Garcia-Muret MP, Alegre M, Puig L. Crusted (Norwegian) scabies: an under-recognized infestation characterized by an atypical presentation and delayed diagnosis. J Eur Acad Dermatol Venereol 2014; 30: 483-5.

14. Hylwa SA, Loss L, Grassi M. Crusted scabies and tinea corporis after treatment of presumed bullous pemphigoid. Cutis 2013; 92: 193-8.

15. Forton FMN, De Maertelaer V. Two consecutive standardized skin surface biopsies: an improved sampling method to evaluate Demodex density as a diagnostic tool for rosacea and demodicosis. Acta Derm Venereol 2017; 97: 242-8.

16. Neynaber S, Muehlstaedt M, Flaig MJ, Herzinger T. Use of Superficial Cyanoacrylate Biopsy (SCAB) as an Alternative for Mite Identification in Scabies. Arch Dermatol 2008; 144: 114-5.

17. Katsumata K, Katsumata K. Simple method of detecting Sarcoptes scabiei var hominis mites among bedridden elderly patients suffering from severe scabies infestation using an adhesive tape. Intern Med 2006; 45: 857-9.

18. Abdel-Latif AA, Elshahed AR, Salama OA, Elsaie ML. Comparing the diagnostic properties of skin scraping, adhesive tape, and dermoscopy in diagnosing scabies. Acta Dermatovenerol Alp Pannonica Adriat 2018; 27: 75-8. 